\title{
THE EFFECT OF LEVOTYROXINE ON THE COURSE OF HEART FAILURE IN PATIENTS WITH NON-TOXIC GOITER*
}

\author{
S. M. Pyvovar ${ }^{1}$, Yu. S. Rudyk ${ }^{1}$, T.V. Lozyk ${ }^{1}$, V. Yu. Galchinskaya ${ }^{1}$, \\ M. Radziejowska ${ }^{2}$, P. Radziejowski ${ }^{2}$ \\ ${ }^{1}$ GI "L. T. Malaya Therapy National Institute of the NAMS of Ukraine», \\ Kharkiv, Ukraine, sn_p@ukr.net; \\ ${ }^{2}$ Czestochowa University of Technology, Częstochowa, Poland, \\ maria.radziejowska@wz.pcz.pl
}

Heart failure (HF) is one of the main causes of hospitalization and mortality in many countries in the world [1]. Last decades, the occurance of the HF has been increasing, indicating that our understanding of the disease pathogenesis is insufficient and new and affordable treatment are needed [2]. Currently HF is considered as a unique scenario of change in systemic homeostasis, in which myocardium, peripheral organs, neuroendocrine and immune systems dysfunctions are chronic cross-links between stress stimul with continual activation of the stress response [2]. Interest in the role of thyroid hormones (TH) in the HF has increased over the last decade. Previous small studies have shown that TH replacement therapy in patients with HF improves cardiac function, increases exercise tolerance [3]. In current international and national standards of $\mathrm{HF}$ treatment, in the absence of hypothyroidism, the use of thyroid hormones is not recommended. At the same time, at non-toxic goiter (NG), which is the most common thyroid pathology, levothyroxine (LT) is a recognized treatment strategy, even in the absence of tyroid gland hypofunction [1]. This makes it possible to study the effect of LT on the course of HF.

The aim is to study the effect of the LT use in patients with NG on the course of HF.

\section{MATERIALS AND METHODS}

The study protocol was approved by the local Ethics and Deontology Committee of Go-

vernment Institution «L. T. Malaya Therapy National Institute». The study procedures were

* The work was performed at the GI «L. T. Malaya Therapy National Institute of the NAMS of Ukraine», The Department of Clinical Pharmacology and Pharmacogenetics of Non-concomitant diseases, with the participation of experts from Czestochowa University of Technology Faculty of Management, Institute of Health Science and Nutrition Czestochowa, Poland.

Institution, which financed the research: NAMS of Ukraine.

The authors assume responsibility for the published work.

The authors guarantee absence of competing interests and their own financial interest when carrying out the research and writing the article.

The manuscript was received by the editorial staff 9.12 .2019 . 
performed in accordance with the ethical standards of the Declaration of Helsinki. Patients were included in the study on the time of hospitalization in the cardiology department due to decompensation of the HF. In the study 218 patients with $\mathrm{HF}$ with NG were included (60 women and 158 men), with a median age of 58.0 [54.0:67.0] years. Criteria of inclusion: signing informed consent, history of myocardial infarction, verified diagnosis of $\mathrm{HF}$ II-IV functional class (FC) by NYHA, non-toxic goiter (NG). Exclusion criteria: no informed consent, severe valvular heart defects, HF of other etiology than myocardial infarction, thyro-suppressive treatment, clinical hypothyroidism, pathothyroidism, inflammatory diseases, other serious pathologies (tumor, tuberculosis) which could complicate treatment or reduce life expectancy.

Diagnosis and treatment of HF were performed in accordance with the recommendations of the European Society of Cardiologists [1].

Serum levels of thyroid-stimulating hormone (TSH) (normal range: $0.3-4.0 \mathrm{mIU} / \mathrm{l}$ ), free $\mathrm{T}_{3}\left(\mathrm{~T}_{3 \mathrm{f}}\right.$ ) (normal range: $2.5-5.8 \mathrm{pmol} / \mathrm{l}$ ) and free $\mathrm{T}_{4}\left(\mathrm{~T}_{4 \mathrm{f}}\right)$ (reagent range: $10-25 \mathrm{pmol} / \mathrm{l}$ ) were determined using reagent kits ("TSH-ELISA», « $\mathrm{T}_{41}$ " and " $\mathrm{T}_{31}$ " by Hema, Ukraine). Levels of reversible triiodothyronine $\left(\mathrm{T}_{3 \mathrm{r}}\right.$ ) (normal range: $90-350 \mathrm{pg} / \mathrm{ml}$ ), and of the N-terminal fragment of the prohormon of the Brain natriuretic peptide (NT-proBNP) (norm $<125 \mathrm{pg} / \mathrm{ml}$ ) were determined using an ELISA kit reagent (Elabscience ${ }^{\circledR}$, China). Immuno-enzymatic studies were performed on a semi-automatic enzyme-linked immunosorbent analyzer «Immunochem-2100» (High technology, USA) No. 501322057FSE. Certificate of last verification № 08-421/2 dated 26.11.2018).

Doppler echocardioscopic examination was performed using the VIVID-3 ultrasound diagnostic system (General Electric, USA). Enddiastolic and end-systolic dimensions (EDD and ESD, respectively) of the left ventricle (LV), the thickness of the interventricular septum (IVS) and the LV posterior wall (LVPW), the diameter of the left atrium (LA), right ven- tricle (RV), other options were determined. The end-diastolic and the end-systolic volumes (LV EDV, LV ESV, respectively) of the LV, the LV ejection fraction (LV EF), the LA index (ILA), the myocardial mass of the LV (MM LV) and its index (IMM LV) were calculated.

The ultrasound examination of a thyroid gland was performed. NG was diagnosed by ultrasound criteria [4] in the absence of signs of thyroid hyperfunction [5].

109 (50 \%) patients (group I) with non-toxic goiter received LT at the time of inclusion in the study (of them $23(21,1 \%)$ had subclinical hypothyreosis, the remaining patients had laboratory evidence of autoimmune thyroiditis). Group II included 109 patients without LT treatment. Patients in both groups did not differ by age and gender (Table 1). The median time of LT treatment before inclusion in the study was 12.0 [10.0; 16.5] months. After hospital discharge, patients were monitored for 2 years, taking into account the presence of re-hospitalization $(\mathrm{RH})$ for decompensation of the HF, mortality. The combined endpoint (CE) was determined according to these indicators.

The normality of indicators distribution was checked using the Shapiro-Wilk test. Data are given as the median $(\mathrm{Me})$ and interquantile (25\% and $75 \%$ ) ranges (for non-normally distributed variables), and as the mean (M) and the standard deviation ( \pm SD) (for ANOVA). Quantitative indicators comparison was performed using a non-parametric criterion Mann-Whitney. Frequency of groups was evaluated by the Pearson chi-squared test $\left(\mathrm{X}^{2}\right)$. The odds ratio (OR) with $95 \%$ confidence interval (CI) was calculated. For comparison of LV EF values in the groups of patients taking different doses of LT a one-way ANOVA was performed with posterior multiple comparison by the Sheffe method. A ROC analysis was used to determine the effect of LT dose on HF over two years. p-value $<0.05$ was considered statistically significant. IBM ${ }^{\circledR}$ SPSS $^{\circledR}$ Statistics, 20.0 and MedCalc, 18.9.1 (free version) software packages were used.

\section{RESULTS AND THEIR DISCUSSION}

The I group of patients, compared to II one, at the time of hospitalization had a high- er serum levels of $\mathrm{T}_{3 \mathrm{f}}$ (by $19 \%, \mathrm{p}=0.01$ ), $\mathrm{T}_{4 \mathrm{f}}$ (by $14.2 \%, \mathrm{p}=0.02$ ) and lower TSH level 
Characteristics of groups of patients

with heart failure with nontoxic goiter $(n=218)$

\begin{tabular}{|c|c|c|c|}
\hline \multirow{2}{*}{ Indicator, units } & \multicolumn{2}{|c|}{$\begin{aligned} \text { Therapy } \\
\end{aligned}$} & \multirow{2}{*}{$X$} \\
\hline & With LT (n = 109) & Without LT (n = 109) & \\
\hline Age, years & $58.0[55.0 ; 67.0]$ & $58.0[54.0 ; 67.0]$ & $>0.05$ \\
\hline $\begin{array}{c}\text { Gender: } \\
\text { - women, } \mathrm{n}(\%) \\
\text { - } \text { men, } \mathrm{n}(\%) \\
\end{array}$ & $\begin{array}{l}31(28.4) \\
78(71.6)\end{array}$ & $\begin{array}{l}29(26.6) \\
80(73.4)\end{array}$ & $\begin{array}{l}0.092 ; \\
>0.05\end{array}$ \\
\hline $\begin{array}{l}\text { NYHA FC: II, n (\%) } \\
\quad \text { - III, n (\%) } \\
\text { - IV, n (\%) }\end{array}$ & $\begin{array}{l}48(44.0) \\
45(41.3) \\
16(14.7)\end{array}$ & $\begin{array}{l}38(34.9) \\
58(53.2) \\
13(11.9)\end{array}$ & $\begin{array}{l}3.114 ; \\
>0.05\end{array}$ \\
\hline SBP mmHg. & $140.0[130.0 ; 160.0]$ & $145.0[130.0 ; 160.0]$ & $>0.05$ \\
\hline DBP, mm Hg. & $90.0[80.0 ; 94.5]$ & $90.0[80.0 ; 95.0]$ & $>0.05$ \\
\hline $\mathrm{HR}, \min ^{-1}$ & $72.0[68.0 ; 82.0]$ & $77.0[68.0 ; 84.0]$ & $>0.05$ \\
\hline BMI, $\mathrm{kg} / \mathrm{m}^{2}$ & $27.7[25.8 ; 31.2]$ & $27.1[25.0 ; 31.1]$ & $>0.05$ \\
\hline $\mathrm{T}_{3 \mathrm{f}}, \mathrm{pmol} / \mathrm{l}$ & $2.5[1.9 ; 3.3]$ & $2.1[1.7 ; 3.1]$ & 0.01 \\
\hline $\mathrm{T}_{4 \mathrm{f}}, \mathrm{pmol} / \mathrm{l}$ & $16.9[13.4 ; 19.4]$ & $14.8[11.4 ; 16.6]$ & 0.02 \\
\hline TSH, & $1.4[0.8 ; 1.9]$ & $2.3[1.1 ; 3.4]$ & 0.0001 \\
\hline $\mathrm{T}_{3 \mathrm{r}}$ & $276.4[201.4 ; 325.4]$ & $292.6[205.6 ; 367.8]$ & $>0.05$ \\
\hline NT-proBNP, pg/ml & $408.0[297.3 ; 681.8]$ & $553.7[339.0 ; 1110.9]$ & 0.009 \\
\hline EDD, $\mathrm{cm}$ & $5.4[5.0 ; 5.8]$ & $5.6[5.2 ; 6.2]$ & 0.009 \\
\hline $\mathrm{EDV}, \mathrm{ml}$ & $143.1[119.9 ; 168.6]$ & $155.6[131.2 ; 196.3]$ & 0.009 \\
\hline $\mathrm{ESD}, \mathrm{cm}$ & $4.1[3.7 ; 4.4]$ & $4.4[4.0 ; 5.1]$ & 0.0001 \\
\hline $\mathrm{ESV}, \mathrm{ml}$ & $74.1[59.1 ; 89.0]$ & $89.0[71.1 ; 125.5]$ & 0.0001 \\
\hline LVEF, \% & $48.1[40.3 ; 55.8]$ & $37.1[30.1 ; 45.8]$ & 0.0001 \\
\hline IMM, g/m ${ }^{2}$ & $108.7[93.5 ; 125.3]$ & $116.5[99.7 ; 132.9]$ & $>0.05$ \\
\hline $\mathrm{LA}, \mathrm{cm}$ & $4.1[3.9 ; 4.4]$ & $4.2[3.9 ; 4.5]$ & $>0.05$ \\
\hline $\mathrm{RV}, \mathrm{cm}$ & $2.6[2.5 ; 2.9]$ & $2.8[2.6 ; 3.0]$ & $>0.05$ \\
\hline $\mathrm{RA}, \mathrm{cm}$ & $3.7[3.4 ; 4.0]$ & $3.7[3.5 ; 4.0]$ & $>0.05$ \\
\hline
\end{tabular}

SBP — systolic blood pressure,

DBP — diastolic blood pressure,

HR - - heart rate,

$\mathrm{BMI}$ - body mass index.

(by $39.1 \%, \mathrm{p}=0.0001$ ). The level of $\mathrm{T}_{3 \mathrm{r}}$ did not differ significantly between groups. Patients who received LT had a lower NT-proBNP level (by $26.3 \%, \mathrm{p}=0.009$ ). Patients who used LT for NG before hospitalization, compared to patients without this treatment, had smaller LV dimensions (EDD and ESD) and volumes (ESV and EDV) (Table 1) and a larger LV EF by $22.9 \%(p=0.0001)$.

The median dose of LT was $0.63[0.35 ; 1.11]$ $\mu \mathrm{g} / \mathrm{kg}$. To identify the association of LVEF with the dose of LT, patients with $\mathrm{HF}$ were divided into 6 subgroups by percentile of dose the drug (Table 2). In the subgroup of patients receiving LT at a dose of 0.1-0.69 $\mu \mathrm{g} / \mathrm{kg}$, LVEF was not different from that in patients without LT. At a dose of $0.7-1.19 \mu \mathrm{g} / \mathrm{kg}, \mathrm{LVEF}$ is higher, compared to that in patients not receiving LT (by $37.9 \%$ ) and compared to patients receiving $\mathrm{LT}$ at a dose of $0.1-0.33 \mu \mathrm{g} / \mathrm{kg}$ (36.9\%).

LVEF was the highest in patients receiving LT at $>1.20 \mu \mathrm{g} / \mathrm{kg}(58.2 \pm 6.7 \%)$. In this subgroup of patients, it was larger compared to that in patients who did not use LT, or took it at a dose of $0.1-0.69 \mu \mathrm{g} / \mathrm{kg}$, but it was not significantly different from that in patients with LT dose 0.7-1.19 $\mu \mathrm{g} / \mathrm{kg}$ (see Table 2).

Observation of patients during 2 years showed that further use of LT for NG reduces the risk of $\mathrm{RH}$ in the cardiac department $(\mathrm{OR}=0.490(0.281-0.857), \mathrm{p}=0.018)$.

A tendency for a reduction in the risk of $\mathrm{CE}$ achieving (by $27.9 \%, \mathrm{p}=0.074$ ) was identified (Table 3). 
Dependence of the left ventricular ejection fraction on the dose of levothyroxine (one-way ANOVA)

\begin{tabular}{|c|c|c|c|c|}
\hline \multirow{2}{*}{ Group } & \multirow{2}{*}{ Dose LT ( $\mathrm{kg} / \mathrm{kg}))$} & \multicolumn{3}{|c|}{ Subset for $a=0.05(M \pm S D$ for $L V$ EF (\%)) } \\
\hline & & 1 & 2 & 3 \\
\hline $\mathrm{I}(\mathrm{n}=109)$ & 0 & $38.5 \pm 11.0$ & & \\
\hline $\mathrm{II}(\mathrm{n}=25)$ & $0.1-0.33$ & $38.8 \pm 10.0$ & & \\
\hline III $(n=19)$ & $0.34-0.59$ & $45.1 \pm 7.0$ & $45.1 \pm 7.0$ & \\
\hline IV $(n=20)$ & $0.6-0.69$ & $46.0 \pm 5.7$ & $46.0 \pm 5.7$ & \\
\hline $\mathrm{V}(\mathrm{n}=22)$ & $0.7-1.19$ & & $53.1 \pm 7.0$ & $53.1 \pm 7.0$ \\
\hline VI $(n=21)$ & $\geq 1.20$ & & & $58.2 \pm 6.7$ \\
\hline \multicolumn{5}{|c|}{$\mathrm{F}=22.4 ; \mathrm{p}=0.0001$} \\
\hline
\end{tabular}

The effect of the use of levothyroxine in non-toxic goiter

Table 3 on the course of heart failure $(n=218)$

\begin{tabular}{c|c|c|c}
\hline \multirow{2}{*}{ Indicator, units } & \multicolumn{2}{|c|}{ Therapy } & \multirow{2}{*}{$\mathrm{X}$} \\
\cline { 2 - 3 } & With LT (n= 109) & Without LT (n= 109) & $6.334 ; 0.012$ \\
\hline $\mathrm{RH}, \mathrm{n}(\%)$ & $32(29.4)$ & $50(45.9)$ & $0.644 ;>0.05$ \\
\hline Death, n (\%) & $9(8.3)$ & $6(5.5)$ & $3.188 ; 0.074$ \\
\hline CE, n (\%) & $39(35.8)$ & $52(47.7)$ & \\
\hline
\end{tabular}

Table 4 Relationship of levothyroxine dose with the risk of re-hospitalization
of patients with heart failure and non-toxic goiter (ROC analysis)

\begin{tabular}{c|c|c|c|c|c|c}
\hline $\begin{array}{c}\text { Indicator, } \\
\text { units }\end{array}$ & $\begin{array}{c}\text { Cut-off } \\
\text { value }\end{array}$ & AUC & $\mathbf{9 5} \%$ CI & $\begin{array}{c}\text { Sensitivity, } \\
\%\end{array}$ & $\begin{array}{c}\text { Specificity, } \\
\%\end{array}$ & $\mathbf{p}$ \\
\hline $\begin{array}{c}\mathrm{LT} \mathrm{dose}, \\
\mu \mathrm{g} / \mathrm{kg}\end{array}$ & $>0.53$ & 0.589 & $0.521-0.655$ & 56.62 & 60.98 & 0.016 \\
\hline
\end{tabular}

The effect of different doses of levothyroxine

Table 5 on the course of heart failure $(n=218)$

\begin{tabular}{|c|c|c|c|c|}
\hline \multirow{2}{*}{ Indicator, units } & \multirow{2}{*}{$\begin{array}{l}\text { Without LT } \\
(\mathrm{n}=109)\end{array}$} & \multicolumn{2}{|c|}{ Dose LT $(\mu \mathrm{g} / \mathrm{kg})$} & \multirow{2}{*}{$\mathrm{x}$} \\
\hline & & $0.1-0.53(n=37)$ & $>0.53(n=72)$ & \\
\hline RH, n (\%) & $50(45.9)$ & $12(32.4)$ & $20(27.8)$ & $6.559 ; 0.038$ \\
\hline
\end{tabular}

During the ROC analysis, it was found out that the risk of $\mathrm{RH}$ in patients with $\mathrm{HF}$ decreases with the use of LT at a dose over $0.53 \mu \mathrm{g} / \mathrm{kg}$ (sensitivity $-56.62 \%$, specificity $60.98 \%, \mathrm{p}=0.016$ ) (table. 4).

According to the results of ROC analysis, patients with $\mathrm{HF}$ with NG were divided for 3 groups. The I one included 109 (50.0\%) patients who did not use LT. In the II group there were $37(16.9 \%)$ patients who continued to take $\mathrm{LT}$ at a dose of $0.1-0.53 \mu \mathrm{g} / \mathrm{kg}$ after inclusion in the study.

In group III there were 72 patients (33.1\%) taking LT at a dose $>0.53 \mu \mathrm{g} / \mathrm{kg}$ (Table 5).
Patients taking LT at dose $>0.53 \mu \mathrm{g} / \mathrm{kg}$ for 2 years had the lowest $\mathrm{RH}$ rate $(27.8 \%)$, compared to dose $0.1-0.53 \mu \mathrm{g} / \mathrm{kg}(32.4) \%$ ) and without prescription of this treatment (45.9\%) $\left(\mathrm{x}^{2}=6.559\right.$, at $\left.\mathrm{p}=0.038\right)$ (see table 5).

Experimental studies have shown that TH counteracts the progression of HF, possibly due to genomic and non-genomic effects in the myocardium and heart vessels and the whole body [6].

Several clinical studies have demonstrated the potential benefits of using thyroid hormones in patients with acute HF [7], the TH treatment reduced the postoperative atrial fi- 
brillation, improved hemodynamic parameters, reducing the need for inotropic drugs and reducing troponin I level [8, 9]. The treatment by thyroid hormones reduced the mortality of patients with open-heart intervention [10]. In heart transplantation, TH led to faster hemodynamic stabilization [11]. Similar effects were also obtained with the use of $\mathrm{TH}$ in addition to dobutamine in patients with acute myocarditis and hemodynamic instability [12].

Current medical practice adheres to avoiding thyroid hormones replacement therapy for HF. This rule probably arose after the publication of the results of the Coronary Drug Project study (1972) [13], where an excessively high dose of the "inactive" right-rotating thyroxine isomer (D-T $)$ was used. Later it became clear that it was converted into a toxic dose of active levothyroxine in the body [3]. Researchers, due to a large dose of $\mathrm{D}-\mathrm{T}_{4}$, sought a significant reduction in serum cholesterol. The results of this study showed a slight increase in the incidence of arrhythmia and mortality [13]. In another Phase II trial on using of DITPA analogue of $\mathrm{TH}$ in $\mathrm{HF}$, some improvements in hemodynamics were demonstrated, but there was no credible improvement in exercise tolerance. It is worth noting that the DITPA study also likely used an overdose because the patients treated had an increase in heart rate, decreased body weight, and diarrhea [14]. In our study, patients who took LT before hospitalization due to $\mathrm{HF}$ did not differ from patients who did not use this drug in terms of systolic and diastolic blood pressure, heart rate, body mass index, probably because of the low dose of LT $(0.63$ [0.35; 1.11] $\mu \mathrm{g} / \mathrm{kg})$.

There is an information on two studies in which patients with non-ischemic cardiomyopathy were treated by synthetic LT (L-T4) used orally at a physiological dose of $100 \mu \mathrm{g} /$ day for a short period ( 1 week) and for 3 consecutive months [15, 16]. LT was well tolerated and led to an improvement in systolic cardiac function and exercise tolerance and decreased systemic vascular resistance. Low dosage of dobutamine (10 $\mathrm{\mu g} / \mathrm{kg}$ per $\mathrm{min}$ ) in the LT group resulted in a significantly higher increase in heart ejection fraction and heart rate than in patients receiving placebo [15, 16]. This may indicate an increase in myocardial adrenergic sensitivity, according to experimental data on the effect of thyroid hormones on the expression of $B_{1}$-adrenoreceptors on the myocyte membrane [17].

The beneficial hemodynamic effects of intravenous LT $(20 \mu \mathrm{g} / \mathrm{h})$ have been reported in 10 patients with cardiogenic shock who did not respond to conventional pharmacological inotropic drugs and intra-aortic balloon counterpulsation [18].

In conclusion, the treatment by thyroid hormones at $\mathrm{HF}$ remains, at this point in time, still an "open book». There are several unanswered questions: the regimen, dose, and schedule of $\mathrm{TH}$ receiving, the effects of this therapy. Large, multicenter, prospective, placebo-controlled studies are needed to provide information on the efficiency, safety, and impact of thyroid hormones on long-term prognosis.

\section{CONCLUSIONS}

The use of levothyroxine in patients with nontoxic goiter in heart failure has a dose-dependent positive effect on the left ventricular ejection fraction. The highest ejection fraction is observed in patients receiving the medicine at a dose over $1.2 \mu \mathrm{g} / \mathrm{kg}$. Receiving of levothyroxine at a dose of $>0.53 \mu \mathrm{g} / \mathrm{kg}$ results in a significant decrease in the rate of repeated hospitalization during 2 years due to heart failure decompensation.

\section{REFERENCES}

1. Ponikowski P, Voors AA, Anker SD, et al. Eur Heart $J$ 2016; 8: 2129-2200. doi: 10.1093/eurheartj/ehw128.

2. Gerdes M, Iervasi G. Circulation 2010; 122: 385-393. doi: 10.1161/CIRCULATIONAHA.109.917922.

3. Zhang Y, Dedkov I, Lee B, et al. J Card Fail 2014; 20(12): 1012-1019. doi:10.1016/j.cardfail.2014.10.003.

4. Cooper DS, Doherty GM, Haugen BR, et al. Thyroid 2009; 19:1167-1214. doi:10.1089/thy.2009.0110.
5. Knobel M. J Endocrinol Invest. 2016;39: 357-373. doi:10. 1007/ s40618-015-0391-7.

6. Pingitore A, Galli E, Barison A, et al. J Clin Endocrinol Metab 2008: 93: 1351-1358.

7. Klemperer JD, Zelano J, Helm RE, et al. J Thorac Cardiovasc Surg 1995; 109: 457-465.

8. Klemperer JD, Klein IL, Ojamaa K, et al. Ann Thorac Surg 1996; 61: 1323-1327. 
9. Ranasinghe AM, Quinn DW, Pagano D, et al. Circulation 2006; 114: I245-I250.

10. Novitzky D, Fontanet H, Snyder M, et al. Cardiology 1996; 87: 509-555.

11. Novitzky D. Thyroid 1996; 6: 531-536.

12. Brokhin M, Klein I. Clin Cornerstone 2005; 7: S28-S29.

13. The Coronary Grug Project Research Group. JAMA 1972; 220: 996-1008.

14. Goldman S, McCarren M, Morkin E, et al. Circulation 2009; 119: 3093-100.
15. Moruzzi P, Doria E, Agostoni PG, et al. Am J Cardiol 1994; 73: 374-378.

16. Moruzzi P, Doria E, Agostoni PG, et al. Am J Med 1996; 101: 461-467.

17. Hammond HK, White FC, Buxton IL, et al. Am J Physiol 1987; 252: H283-H290.

18. Malik FS, Mehra MR, Uber PA, et al. J Card Fail 1996; 5: 31-37.

\title{
ВПЛИВ ЛЕВОТИРОКСИНУ \\ НА ПЕРЕБІГ СЕРЦЕВОÏ НЕДОСТАТНОСТІ \\ У ХВОРИХ 3 НЕТОКСИЧНИМ ЗОБОМ
}

\author{
Пивовар С. М. ${ }^{1}$, Рудик Ю. С. ${ }^{1}$, Лозик Т. В. ${ }^{1}$, Гальчинська В. Ю. ${ }^{1}$ \\ Радзіевська М. ${ }^{2}$, Радзіевський П. ${ }^{2}$ \\ ${ }^{1}$ ДУ «Національний інститут терапї̈ іл. Л. Т. Малої НАМН Украӥни», \\ м. Харків, Україна, \\ sn_p@ukr.net; \\ 2 Ченстоховський технологічний університет, Ченстохова, Польща, \\ maria.radziejowska@wz.pcz.pl
}

До дослідження включено 218 хворих з серцевою недостатністю (CH) на фоні післяінфарктного кардіосклерозу, що мали нетоксичний зоб (Н3). 109 (50,0 \%) хворих отримували левотироксин (ЛТ) у звязку з НЗ. Визначали рівні ТТГ, $\mathrm{T}_{3 \mathrm{~B}}, \mathrm{~T}_{4 \mathrm{~B}}, \mathrm{~T}_{3 \mathrm{r}}$. Проводили ехокардіоскопію та ультразвукове дослідження щитоподібної залози. Вивчали перебіг СН протягом 2 років. Хворі, що застосовували ЛТ 3 приводу НЗ, порівнюючи до паціентів без даного препарату, мали менші розміри (КДР та КСР) та об’еми (КДО та КСО) лівого шліночка (ЛШ) та більшу на 22,9 \% величину фракцію викиду (ФВ) ЛШ ( p = 0,009). У підгрупі хворих, котрі приймали ЛТ у дозі від 0,1 до 0,69 мкг/кг, ФВ ЛШ не відрізнялася від паціентів, що не застосовували даний препарат. При дозі 0,7-1,19 мкг/кг, ФВ ЛШ е більшою, порівнюючи до такої у пацієнтів, що не приймали ЛТ (на 37,9 \%) та в порівнянні до хворих, що приймали ЛТ в дозі 0,1-0,33 мкг/кг (на 36,9 \%). ФВ ЛШ була найвищою у пацієнтів, що приймали ЛТ у дозі $>$ 1,20 мкг/кг. Застосування ЛТ з приводу НЗ протягом 2 років зменшуе ризик повторної госпіталізації (ПГ) з приводу декомпенсації СН (відношення шансів $=0,490(0,281-0,857), \mathrm{p}=0,018)$ та тенденційне зниження ризику досягнення комбінованої кінцевої точки (на 27,9%, p = 0,074). За допомогою ROC-аналізу встановлено, що ризик ПГ хворих на СН з приводу декомпенсації захворювання, зменшуеться при застосуванні ЛТ в дозі > 0,53 мкг/кг (чутливість - 56,62 \%, специфічність - 60,98 \%, $\mathrm{p}=0,016)$. Застосування левотироксину у хворих з нетоксичним зобом при серцевій недостатності має дозозалежний позитивний вплив на фракцію викиду лівого шлуночка. Найвища фракція викиду лівого шлуночка спостерігається у хворих, що приймали препарат в дозі > 1,2 мкг/кг. Застосування левотироксину в дозі > 0,53 мкг/кг при нетоксичному зобі призводить до вірогідного зниження частоти повторної госпіталізації у зв’язку з декомпенсацією серцевої недостатності протягом 2 років.

К л ючові слова : серцева недостатність, нетоксичний зоб, левотироксин, фракція викиду, перебіг захворювання. 


\title{
ВЛИЯНИЕ ЛЕВОТИРОКСИНА \\ НА ТЕЧЕНИЕ СЕРДЕЧНОЙ НЕДОСТАТОЧНОСТИ У БОЛЬНЫХ С НЕТОКСИЧЕСКИМ ЗОБОМ \\ Пивовар С. Н. ${ }^{1}$, Рудык Ю. С. ${ }^{1}$, Лозык Т. В. ${ }^{1}$, Гальчинская В. Ю. ${ }^{1}$, Радзиевская М. ${ }^{2}$, Радзиевскый П. ${ }^{2}$ \\ ${ }^{1}$ ГУ «Национальный институт терапии ил. Л. Т. Малой НАМН Украины», г. Харьков, Украина, sn_p@ukr.net; \\ ${ }^{2}$ Ченстоховский технологический университет, Ченстохова, Польша, maria.radziejowska@wz.pcz.pl
}

В исследование включено 218 больных с сердечной недостаточностью (CH) на фоне постинфарктного кардиосклероза, которые имели нетоксический зоб (НЗ). 109 (50,0%) больных получали левотироксин в связи с НЗ. Определяли уровни ТТГ, $\mathrm{T}_{\text {зсв }}, \mathrm{T}_{4 с в}, \mathrm{~T}_{3 \mathrm{r}}$. Проводили эхокардиоскопию и ультразвуковое исследование щитовидной железы (ЩЖ). Изучали течение СН на протяжении 2 лет. Больные, которые применяли ЛТ, сравнивая с пациентами без данного препарата, имели меньшие размеры (КДР и КСР) и объемы (КДО и КСО) Левого желудочка (ЛЖ) и большую на 22,9 \% величину фракции выброса (ФВ) ЛЖ ( $\mathrm{p}=0,0001)$, а также более низкий сывороточный уровень NT-proBNP (на 26,3 \%, p = 0,009). В подгруппе больных, принимавших ЛТ в дозе от 0,1 до 0,69 мкг/кг, ФВ ЛЖ не отличалась от пациентов, не применявших этот препарат. При дозе 0,7-1,19 мкг/кг, ФВ ЛЖ была большей, по сравнению с таковой у пациентов, не принимавших ЛТ (на 37,9\%) и в сравнении с больными, принимавших ЛТ в дозе 0,1-0,33 мкг/кг (на 36,9\%). ФВ ЛЖ была наибольшей у пациентов, принимавших ЛТ в дозе $>1,20$ мкг/кг. Применение ЛТ на протяжении 2 лет уменьшает риск повторной госпитализации (ПГ) по поводу декомпенсации СН (отношение шансов $=0,490(0,281-0,857), \mathrm{p}=0,018)$ и тенденциозное снижение риска достижения кобинированной конечной точки (на 27,9\%, p = 0,074). C помощью ROC-анализа установлено, что риск ПГ больных с СН по поводу декомпенсации заболевания, уменьшается при применении ЛТ в дозе > 0,53 мкг / кг (чувствительность - 56,62\%, специфичность - 60,98\%, p = 0,016). Применение ЛТ у больных имеет дозозависимое положительное влияние на ФВ ЛЖ. Наибольшая ФВ ЛЖ наблюдается у больных, принимавших препарат в дозе > 1,2 мкг/кг. Применение ЛТ дозе $>0,53$ мкг/кг приводит к достоверному снижению частоты повторной госпитализации в связи с декомпенсацией сердечной недостаточности на протяжении 2-х лет.

К лючевые слова: сердечная недостаточность, нетоксический зоб, левотироксин, фракция выброса, течение заболевания.

\section{THE EFFECT OF LEVOTYROXINE ON THE COURSE OF HEART FAILURE IN PATIENTS WITH NON-TOXIC GOITER}

\author{
S. M. Pyvovar ${ }^{1}$, Yu. S. Rudyk ${ }^{1}$, T.V. Lozyk ${ }^{1}$, V. Yu. Galchinskaya ${ }^{1}$, \\ M. Radziejowska ${ }^{2}$, P. Radziejowski² \\ ${ }^{1}$ GI «L. T. Malaya Therapy National Institute of the NAMS of Ukraine», \\ Kharkiv, Ukraine, \\ sn_p@ukr.net; \\ ${ }^{2}$ Czestochowa University of Technology, Częstochowa, Poland, \\ maria.radziejowska@wz.pcz.pl
}

The study included 218 patients with heart failure (HF) on the background of post-infarction cardiosclerosis who had non-toxic goiter (NG). 109 (50.0 \%) patients received levothyroxine (LT) in connection with NG. Whether the levels of TSH, $\mathrm{T}_{3 \mathrm{f}}, \mathrm{T}_{4 \mathrm{f}}, \mathrm{T}_{3 \mathrm{r}}$ were determined. Echocardioscopy and ultrasound examination of the thyroid gland were conducted. We studied the course of heart failure for 2 years. Patients who used LT, comparing with patients without this drug, had smaller dimensions (EDD and ESD) and volumes (ESV and EDV) of left ventricle (LV) and $22.9 \%$ greater LV ejection fraction $(\mathrm{EF})(\mathrm{p}=0.0001)$, as well as higher low serum NT-proBNP level (26.3\%, p = 0.009). In the subgroup of patients taking LT at a dose of 0.1 to $0.69 \mathrm{\mu g} / \mathrm{kg}, \mathrm{LVEF}$ did not differ from patients without this tritment. At a dose of 0.7-1.19 $\mu \mathrm{g} / \mathrm{kg}, \mathrm{LVEF}$ is higher compared with that of patients who did not take LT (by 37.9\%) and patients who took LT at a dose $0.1-0.33 \mathrm{mcg} / \mathrm{kg}(36.9 \%)$. LVEF was the highest in patients taking LT at a dose of $>1.20 \mathrm{mcg} / \mathrm{kg}$. The use of LT for 2 years reduces the risk of re-hospitalization $(\mathrm{RH})$ due to decompensation of heart failure (Odds ratio $=0.490(0.281-0.857)$, $p=0.018$ ) and a tendentious decrease in the risk of combined endpiont achieving (by $27.9 \%, p=0.074$ ). The ROC analysis showed that the risk of $\mathrm{RH}$ in patients with heart failure due to decompensation of the disease decreases with the use of LT at a dose of $>0.53 \mu \mathrm{g} / \mathrm{kg}$ (sensitivity $-56.62 \%$, specificity $-60.98 \%, \mathrm{p}=0.016$ ). The use of LT in patients has a dose-dependent positive effect on LVEF. The largest LVEF is observed in patients taking the drug at a dose of $>1.2 \mathrm{mcg} / \mathrm{kg}$. The use of an LT dose of $>0.53 \mathrm{mcg} / \mathrm{kg}$ leads to a significant decrease in the frequency of re-hospitalization due to decompensation of heart failure during 2 years.

Key words: heart failure, non-toxic goiter, levothyroxine, ejection fraction, course of the disease. 